\title{
Epidemiological Profile of Leprosy in the Brazilian state of Piauí between 2003 and $2008^{*}$
}

\author{
Perfil epidemiológico da hanseníase no estado do Piauí, período de 2003 a 2008
}

\author{
Manoel Wilkley Gomes de Sousa ${ }^{1}$ \\ Lucianna Rodrigues Carneiro ${ }^{1}$ \\ Ana Lúcia França da Costa ${ }^{2}$
}

\author{
Darline Carvalho Silva ${ }^{1}$ \\ Maria Luisa Brito Ferreira Almino ${ }^{1}$
}

\begin{abstract}
BACKGROUND: Leprosy is a chronic infectious disease caused by Mycobacterium leprae. It is considered a major public health issue in developing countries.

Овјестілеs: To evaluate the clinical and epidemiological profile of leprosy patients between 2003 and 2008 in the state of Piauí, to analyze detection and prevalence rates in the general population and in the population of children under 15 years of age, and to evaluate the predominant clinical forms.

Methods: Data were obtained from the notifiable diseases database of the State Health Department, Piauí, Brazil. Medical records are retrieved from patients' charts using a specific questionnaire and the collected data is then entered into the database system.

RESULTS: Of the 12,238 cases of leprosy reported in this period, $85 \%$ represented new cases. The mean overall annual detection rate was 54 cases/100,000 habitants. The rate for children under 15 years of age was 15.3 cases/100,000 habitants. Overall, $52.18 \%$ of the patients were male; $64.66 \%$ were between 20 and 59 years of age; and $53.53 \%$ had the paucibacillary form of leprosy. Nevertheless, in $88.82 \%$ of cases of the paucibacillary form of the disease, more than five lesions were present, while in $10.55 \%$ of cases of the multibacillary form of the disease, no lesions were present. Over $20 \%$ of patients had some degree of disability.

Conclusion: These indicators point to a high circulation of bacilli in the community and highlight the extreme difficulty experienced by the primary healthcare network in organizing itself in order to ensure that patients with this complex disease receive an accurate and early diagnosis.
\end{abstract}

Keywords: Disease notification; Epidemiologic surveillance; Healthcare systems; Leprosy.

Resumo: Fundamentos: A hanseníase é uma doença infecciosa crônica, causada pelo Mycobacterium leprae, sendo considerada um grande problema de saúde pública nos países em desenvolvimento.

Овјетіvos: Objetivou-se estudar o perfil clinicoepidemiológico dos pacientes com hanseníase no período de 2003 a 2008, no estado do Piauí, verificar suas taxas de detecção e de prevalência na população geral e em menores de 15 anos e avaliar as formas clínicas predominantes.

MÉTODOs: Os dados foram obtidos a partir da base do Sistema de Informação de Agravos de Notificação da Secretaria de Saúde do estado do Piauí, sendo as informações procedentes dos prontuários médicos, organizadas em um questionário específico.

Resultados: Do total de 12.238 casos de hanseníase notificados no período em questão, $85 \%$ eram casos novos (taxa de detecção geral anual média de 54 casos/100.000 habitantes e em menores de 15 anos de 15,3/100.000 habitantes); $52,18 \%$ eram homens, $64,66 \%$ dos pacientes encontravam-se na faixa etária de 20 a 59 anos e 53,53 \% apresentavam a forma paucibacilar. No entanto, $88,82 \%$ das formas paucibacilares apresentavam mais de cinco lesões e $10,55 \%$ das formas multibacilares não tinham qualquer lesão. Mais de $20 \%$ dos pacientes tinham algum grau de incapacidade.

ConCluSÃo: Conclui-se que estes indicadores apontam para uma elevada circulação do bacilo na comunidade e a grande dificuldade que a rede básica apresenta de se organizar de forma a diagnosticar correta e precocemente os casos desta complexa doença.

Palavras-chave: Hanseníase; Notificação de doenças; Sistemas de saúde; Vigilância epidemiológica

Received on 20.01.2011

Approved by the Advisory Board and accepted for publication on 25.05.2011.

* This study was conducted at the Department of Dermatology, School of Medical Sciences, State University of Piauí (FACIME-UESPI) in association with the Notifiable Diseases Database, State Department of Health (SESAPI), Teresina (PI), Brazil.

Conflict of interest: None

Financial Support: Brazilian National Council for Scientific and Technological Development (CNPq), Grant \# 123365/2008 2.

Medical Degree awarded by the State University of Piauí (UESPI), Teresina (PI), Brazil.

Master Degree, Professor. Department of Dermatology, School of Medical Sciences, State University of Piauí (FACIME-UESPI). Department of Dermatology, Health Sciences Center, Federal University of Piauí (CCS-UFPI), Teresina (PI), Brazil. 


\section{INTRODUCTION}

Leprosy is a chronic, infectious disease caused by Mycobacterium leprae. It is considered a major public health issue in developing countries. It is estimated that only one-third of cases are notified and that, of these, many patients either fail to comply with treatment or discontinue therapy, increasing the impact of the disease. ${ }^{1}$ After entering the organism, if it is not destroyed, it will invade Schwann cells and skin macrophages. Its affinity for the skin and the peripheral nerves grants peculiar characteristics to this disease, making diagnosis simple in the majority of cases. On the other hand, neurological damage is responsible for the sequelae that may develop. ${ }^{2}$

Early diagnosis of the disease and immediate recognition of leprosy reactional states guarantee interruption of the chain of transmission and prevent physical disabilities. Despite the indisputable advances in actions for the control of this disease, it remains a significant problem in Brazil and worldwide, with a need for more realistic strategies and goals for its control. Education and information on this pathology are important, not only for combating feelings of rejection in the patients, but also for adopting effective means of prevention obtained by increasing awareness of the first signs of the disease. ${ }^{3,4}$

The objectives of the present study were to evaluate the clinical and epidemiological profile of leprosy patients between 2003 and 2008 in the Brazilian state of Piauí and to analyze the detection and prevalence rates in the general population and in the population of children under 15 years of age. Another objective was to evaluate the predominant clinical forms of the disease, thus contributing towards determining the most appropriate direction that public policies should assume with respect to leprosy control.

\section{METHODS}

The present study consists of a quantitative and qualitative, retrospective, descriptive study on the epidemiological profile of cases of leprosy registered in the Brazilian state of Piauí between January 2003 and December 2008. The data were obtained from the notifiable diseases database (SINAN) at the Piauí State Health Department. All patients diagnosed with leprosy in the abovementioned period, irrespective of the form of the disease, were included in the study. In addition, patients with a diagnosis of leprosy who had been transferred from other healthcare units for various reasons, and patients with a relapse or other forms of admission, were also included in the study. Patients undergoing investigation for leprosy but whose diagnosis was not concluded during the study period were not included in the study.

\section{Study variables and data collection}

The study population was selected from the SINAN data. The database was built using medical records retrieved from patients' charts through a specific questionnaire. The database system is categorized according to patients' age, gender and place of birth, the clinical form of the disease based on the Madrid classification and on the operational criteria of the Ministry of Health and the World Health Organization (WHO). Information is also available on the characteristics of the case (new, relapse, etc.), the number of skin lesions presented, the degree of physical disability at the time of diagnosis and following the end of treatment when the patient was considered cured, and the type of treatment used.

The Epi Info software program, version $6.04 \mathrm{~d}$ (Centers for Disease Control and Prevention, Atlanta, GA, USA) was used to create a tabular database and to carry out statistical analysis.

\section{Ethical considerations}

The recommendations outlined in the National Health Council Regulation \#196 and their correlated guidelines were strictly adhered to throughout the entire study. This survey study was part of a doctoral thesis defended by one of the authors of the present paper, the objective of which was to associate singlebase polymorphisms in innate immunity genes with leprosy. The study was submitted to the internal review board of the Federal University of Piauí in accordance with the guidelines laid out in Resolution 196/96 of the National Health Council, which regulates research studies involving human beings. The study was approved under reference number $115 / 2006$.

\section{RESULTS}

Of 12,238 cases of leprosy notified between January 2003 and December 2008 at SINAN in the state of Piauí, 10,499 consisted of new cases. Of the remaining cases, 323 referred to relapses, 1,105 referred to patients transferred from other municipalities in the state of Piauí or from other states or other countries, and 311 consisted of cases in which the form of entry was different or for which no information was available. The distribution of patients by gender shows that $52.18 \%$ were male and $47.82 \%$ female. In three cases, no information was available on gender. According to age group, $91.5 \%$ of the patients were 15 years of age or older, while $8.5 \%$ were under 15 years of age. The frequency of cases increased with age, with the highest incidence being in the 20-59 years age group (Graph 1). 


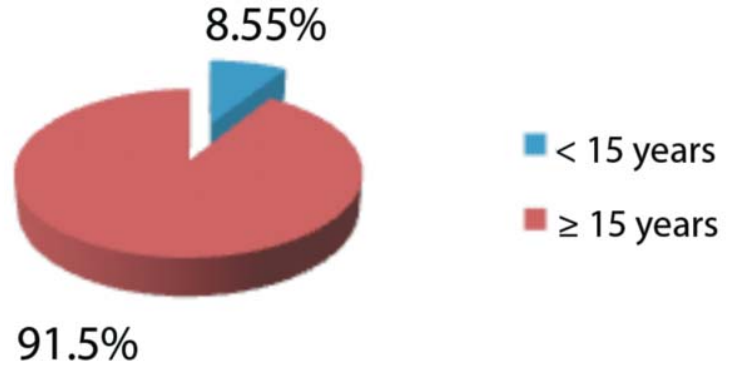

GRAPH 1: Distribution of cases of leprosy according to age group. Piauí, 2003-2008

During the study period, a mean overall detection rate of 54/100,000 inhabitants was found in the state of Piauí, while for the under-15s the mean detection rate was 15.3/100,000 inhabitants (Graph 2). Regarding the clinical form of the disease, according to the operational classification, the majority of patients from the 2003-2008 period were found to have the paucibacillary form (53.53\%). In 55 cases, there was no information available on the form of the disease (Graph 3).

According to the Madrid classification, the predominant form of the disease was the indeterminate type $(27.89 \%)$, as shown in graph 4 . In relation to the operational classification and the number of skin lesions, it was found that in $88.2 \%$ of cases of the paucibacillary form of the disease, more than five lesions were present, while $2.15 \%$ had $2-5$ lesions and $9.00 \%$ had no lesions at all. On the other hand, in the multibacillary form, $78.55 \%$ of the patients had more than five skin lesions, $10.90 \%$ had five lesions or fewer and 10.55 of patients had no skin lesions, as shown in graph 5 .

In $52.71 \%$ of patients, the therapeutic regimen used was the 6-dose multidrug therapy (MDT) for paucibacillary leprosy, while $44.65 \%$ received the 12 dose MTD regimen for multibacillary leprosy and $2.14 \%$ were submitted to other therapeutic regimens in the $2003-2008$ period (Graph 6).

At the time of diagnosis, $99.27 \%$ of the patients were evaluated with respect to their degree of disability. The majority of patients $(69.50 \%)$ were found to have no disability at all at the time of diagnosis; however, some degree of disability was found in a small proportion of patients, as shown in graph 7 .

At the time at which the patient was considered cured (at the end of the multidrug therapy), data on his/her clinical evaluation were only available in $63.65 \%$ of cases, meaning that it was impossible to perform an accurate analysis of any trend that might have occurred during the study period (Graph 8).

\section{DISCUSSION}

Leprosy is a chronic infectious disease caused by Mycobacterium leprae, which was first described in 1873 by the Norwegian scientist Amauer Hansen. It is an intracellular acid-fast bacillus with an affinity for Schwann cells and skin macrophages. Man is considered the only natural reservoir of the bacillus, although there have been reports of naturally infected wild animals (armadillos and monkeys). Patients with the multibacillary forms of the disease are considered the principal source of infection; nevertheless, the role of paucibacillary forms in the chain of transmission has already been demonstrated..$^{5-7}$

The spread of leprosy in the state of Piauí can be analyzed as the result of the improved capacity of the healthcare network to deal with the spontaneous demand in recent years, thus guaranteeing increased access. However, it is also associated with the maintenance of the chain of transmission of the disease, with a high probability of risk of exposure to $M$. leprae, as shown by the high detection rate in children under 15 years of age. ${ }^{8}$

The data collected over the study period reveal characteristics of what the World Health Organization defines as a hyperendemic area, since the detection rate of new cases was high and the prevalence of the disease in all the years of the study was consequently high, principally in 2003 and 2008. ${ }^{9}$ The unexpectedly sharp variation (for the patterns of this disease) in the operational and epidemiological indicator curves in the 6-year study period, to a great extent a consequence of operational issues within the healthcare network, should be emphasized.

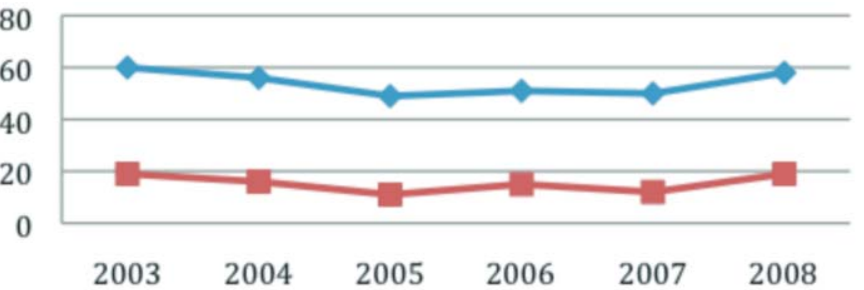

GRAPH 2: Coefficients of leprosy detection: overall detection rate and the detection rate for children under 15 years of age per 100,000 inhabitants. Piauí, 2003-2008 


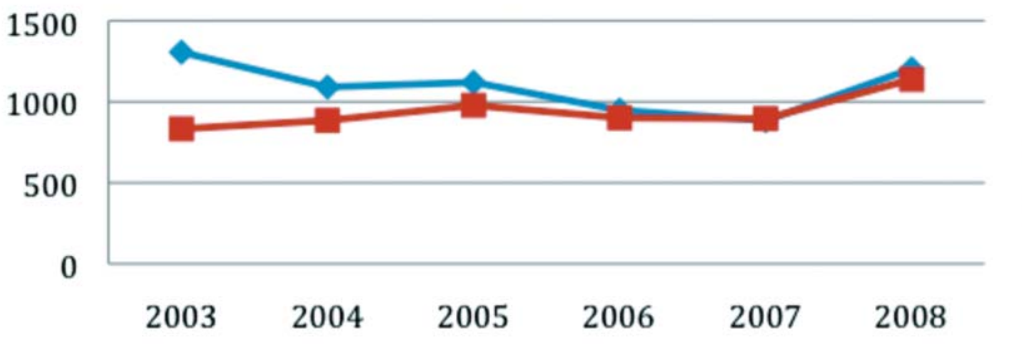

In general, the coefficients of detection of cases of leprosy are higher among males. The reason for this is generally considered to be the risk of exposure; however, the increasing number of cases among females is worthy of mention. Some studies show that leprosy affects more men than women. Nevertheless, there are exceptions such as in the study conducted by Gomes et al. ${ }^{10}$ This small increase in the rates may be the result of an increase in the number of infected women or may be due to a more effective identification of these carriers. An improvement in the access of women to healthcare services and the fact that women are more concerned with their self-image than men could explain this increase in the identification of female cases. ${ }^{11}$

According to these data, the study shows that leprosy affects predominantly young adults rather than children. However, the detection rate in the under-15s continues to be high. Between 2003 and 2008 , the detection rate of leprosy in Brazilian children under 15 years of age was 7.2/100,000. In the same period, the coefficient for the northeastern region of the country was $10.6 / 100,000$ and in the state of Piauí the rate was $15.4 / 100,000$, revealing very high levels of endemicity. The maintenance of high endemic levels of leprosy suggests that children may be contacts of cases not yet detected by the healthcare system. ${ }^{12}$ In conditions of high transmissibility and early exposure to the bacillus, the probability of becoming ill increases; therefore, detection in this age group can be taken as an indicator of the greater severity of the endemic state of the disease. ${ }^{4,13,14}$ Brazil cur- rently uses the coefficient indicators of overall detection (number of cases diagnosed in the period per 100,000 inhabitants) and detection rates in children under 15 years of age (number of cases diagnosed in this age group per 100,000 inhabitants) to evaluate the endemic state of the disease. Areas are classified as follows: low endemic area $(<2$ cases/100,000 inhabitants), moderate ( 9 cases $/ 100,000$ inhabitants), high (19 cases/100,000 inhabitants), very high (39 cases $/ 100,000$ inhabitants) and hyperendemic ( $\geq 40$ cases/100,000 inhabitants). ${ }^{15}$ High rates are generally associated with low levels of socioeconomic development and unsatisfactory healthcare conditions, in addition to the precarious training of healthcare professionals to provide early diagnosis, standardized treatment and to monitor cases. ${ }^{16,12}$ In this age group ( $<15$ years), it was found that $1 \%$ of patients had some degree of disability at the time of diagnosis (grade 1: reduced sensitivity in the eyes, hands and/or feet and grade 2: disability or deformity in the eyes, hands and/or feet). Furthermore, $8.7 \%$ of the patients had 2-5 skin lesions and 9.2\% had more than 5 lesions. Amador et al. (2001) reported that in children under five years of age leprosy may be potentially disabling due to the young age at which the disease was contracted and the possibility of determining deformities, although the occurrence of severe disabilities in children is uncommon. ${ }^{12}$

On the other hand, the number of cases was found to increase with age, with the disease affecting principally the economically active population of 20-59 years of age (64.66\%) and, to a lesser extent, those over

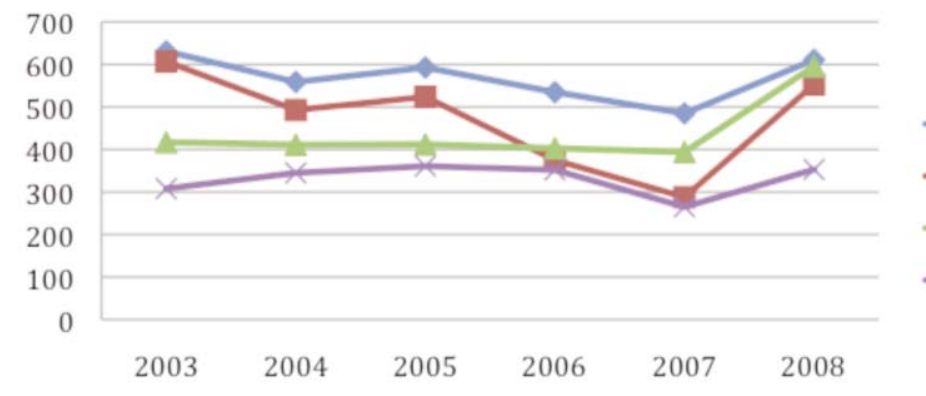

GRAPH 4: Number of new cases of leprosy according to the clinical form of the disease.

Piauí, 2003-2008 


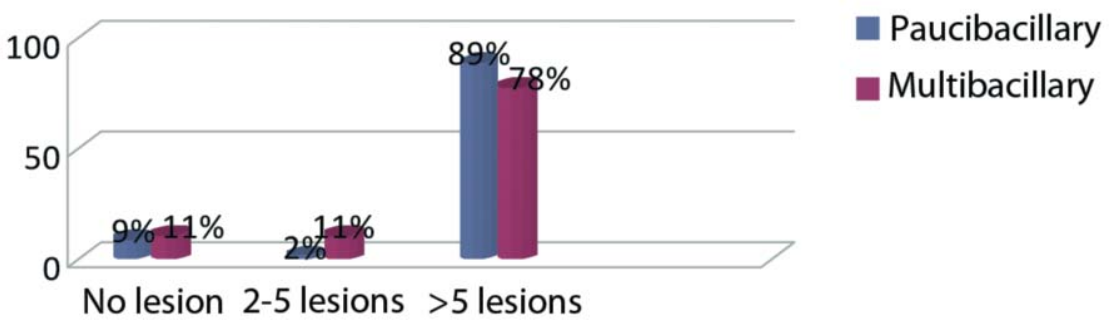

GRAPH 5: Distribution of cases of leprosy (\%) according to the operational classification and the number of skin lesions at the time of diagnosis. Piauí, 2003-2008.

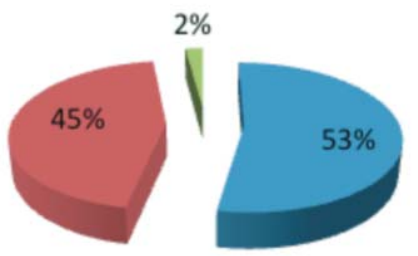

=6-dose multidrug therapy (MDT) for paucibacillary cases

= 12-dose MTD for multibacillary cases

Graph 6: Cases of leprosy in accordance with the therapeutic regimen used. Piauí, 2003-2008.

= Other therapeutic regimens.

60 years of age (19.4\%). This indicates that the economically active population is the segment most affected by leprosy, which may exert a negative impact on the economy of the state, since this segment of the population may go on to develop disabilities, lesions or leprosy reactional states that would remove them from productive activity and generate high social costs. ${ }^{1}$

In agreement with reports from previous studies, the operational classification of leprosy showed that the occurrence of the multibacillary forms in this state had increased by $26 \%$ and that there was a directly proportional relationship with increased age. ${ }^{17-19}$ This association between the clinical form of the disease and age may be the result of the long incubation period of the disease and failure to diagnosis it at an early stage.

With respect to the clinical form of the disease, defined in accordance with the Madrid classification, the majority of patients had the indeterminate form (27.89\%) and a relative similarity was found between the number of cases with the tuberculoid forms (23.21\%) and the dimorphous forms (21.51\%), and, to a lesser extent the virchowian form (16.21\%). It is important to emphasize the considerable increase in the number of multibacillary cases (dimorphous, virchowian) detected in 2008, a fact that may be associated with the discovery of an accumulation of old cases, generally older individuals. Nevertheless, the unexpected increase in the number of cases of leprosy in the elderly and of the dimorphous group in 2008 raised doubts with respect to the appropriateness of the diagnostic process. ${ }^{20,21}$

Approximately $90 \%$ of individuals classified as paucibacillary had more than five skin lesions at the time of diagnosis, in contrast with data reported in the current literature. According to the Ministry of Health, individuals are considered paucibacillary when they have between 1 and 5 skin lesions and a negative acidfast smear. $^{8,22}$ In the multibacillary form of the disease, on the other hand, $78.55 \%$ of the patients had more than 5 skin lesions, which is in agreement with data in the literature. ${ }^{15,23}$ However, more than $10 \%$ of the patients classified as having the multibacillary form of leprosy had no skin lesions at all. These findings may be associated with the inadequate diagnosis process in the healthcare network, possibly reflecting the precarious university training that is given with respect to this disease in Brazil. Despite the increase in the number of medical schools and the improvement in coverage brought about by actions of leprosy control in primary healthcare, an inadequate diagnosis process ultimately results in serious consequences in relation to the implementation of therapy and patients' prognosis. ${ }^{14,20,24}$

Nerve damage causes sensitivity and motor alterations, leading to various degrees of physical disability that may affect patients' social and economic life, resulting in their stigmatization and discrimination. $^{25}$ Although the majority of cases analyzed have no disability at the time of diagnosis (69.5\%), a significant proportion of patients do have some form of disability (23.82\%), as shown in graph 7 . However, $54.33 \%$ of cases were not reevaluated after being considered cured, which did not permit an accurate analysis to be made of any trend that may have been present during the study period. This fact also highlights the precarious follow-up of the patients and the deficiencies in the data system (Graph 8). Deformities 


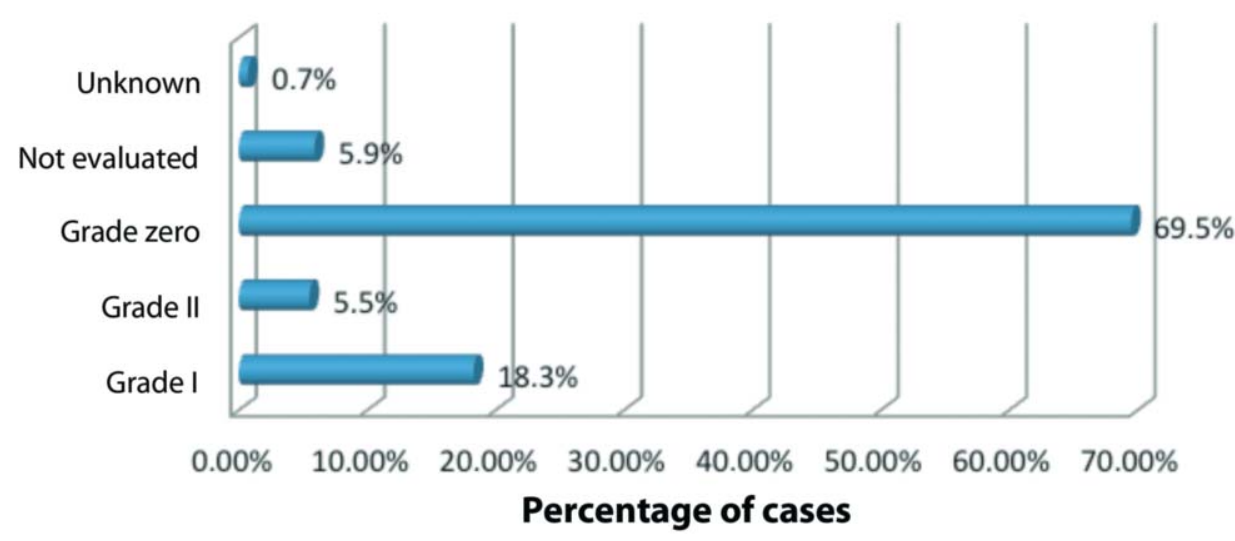

GraPh 7: The degree of disability in leprosy patients at the time of diagnosis.

Piauí, 2003-2008.

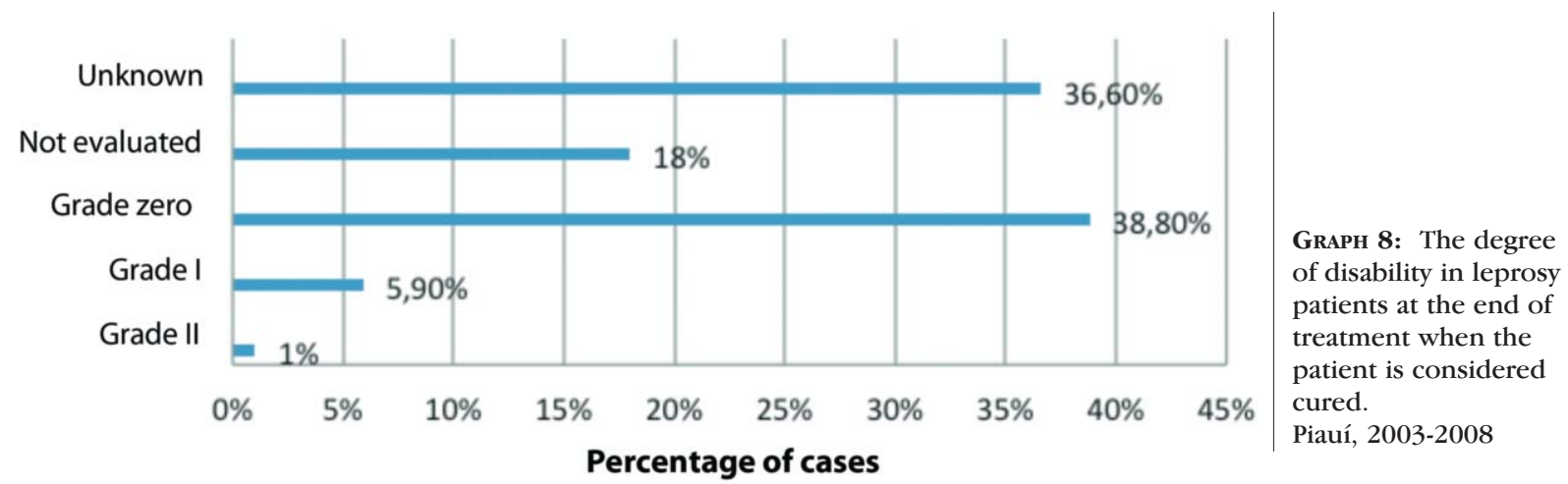

and physical disabilities are the principal problem in leprosy, the percentage of patients with physical disabilities being an indicator of the impact of the disease. ${ }^{26}$ The data found in the present study show a significant number of patients in the economically active age group under a risk of being excluded from the production chain as a consequence of the delay in diagnosing the disease.

\section{CONCLUSION}

In the present study, high rates of leprosy detection in the general population and in children under 15 years of age were found in the state of Piauí for the 2003-2008 period and there was inconsistency in the classification of cases. These indicators show a high circulation of the bacillus in the community and highlight the deficiencies of the primary healthcare network in diagnosing and treating leprosy in a timely and correct fashion. 


\section{REFERENCES}

1. Miranzi SSC, Pereira LHM, Nunes AA. Perfil epidemiológico da hanseníase em um município brasileiro, no período de 2000 a 2006. Rev Soc Bras Med Trop. 2010:43:62-7.

2. Lastória JC, Macharelli CA, Putinatti MSMA. Hanseníase: realidade no seu diagnóstico clínico Hansen Int. 2003;28:53-8.

3. Santos AS, Castro DS, Falqueto A. Fatores de risco para transmissão da Hanseníase. Rev Bras Enferm Brasília. 2008;61(Esp):738-43

4. Imbiriba EB, Hurtado-Guerra JC, Garnelo L, Levino A, Cunha MG, Pedrosa V. Perfil epidemiológico da hanseníase em menores de quinze anos de idade, Manaus (AM), 1998-2005. Rev Saúde Pública. 2008;42:1021-6.

5. Datasus.org [Internet]. Ministério da Saúde. Departamento de Informática do SUS. Informações de saúde. Brasília: Ministério da Saúde; 2007. [acesso 5 Jan 2011]. Disponível em: http://www2.datasus.gov.br/DATASUS/index.php?acao =1

6. Durães SMB, Guedes LS, Cunha MD, Cavaliere FAM, Oliveira MLWDR. Estudo de 20 focos familiares de hanseníase no município de Duque de Caxias, Rio de Janeiro. An Bras Dermatol. 2005;80(Supl 3):S295-300.

7. Vieira AG. Aspectos epidemiológicos, clínicos, imunológicos e histopatológicos dos contatos de hanseníase adoecidos durante seguimento de 5 anos no Município de Duque de Caxias [tese]. Rio de Janeiro (RJ): Universidade Federal do Rio de Janeiro; 2009.

8. Portal.saude.gov [Internet]. Ministério da Saúde. Secretaria de Vigilância em Saúde. Vigilância em Saúde: situação epidemiológica da hanseníase no Brasil. Brasília: Ministério da Saúde; 2008. [accessed 5th January, 2011]. Available at: http://portal.saude.gov.br/portal/saude/Gestor/area.cfm?id_area $=1498$

9. Oliveira BFA, Ignotti E, Hartwuig SV, Scatena SH, Andrade VLG. Acréscimo na detecção de casos de hanseníase como resultado da vigilância de comunicantes em 15 municípios considerados prioritários do estado de Mato Grosso, Brasil. Espaç Saúde. 2007;8:11-9.

10. Gomes CCD, Penna GO, Aires MAP, Gonçalves HS. Perfil clínico-epidemiológico dos pacientes diagnosticados com hanseníase em um centro de referência na região nordeste do Brasil. An Bras Dermatol. 2005;80(Suppl.3):S283-8.

11. Campos SSL, Ramos Jr AN, Kerr-Pontes LRS, Heukelbach J. Epidemiologia da hanseníase no Município de Sobral, Estado do Ceará-Brasil, no Período de 1997 a 2003. Hansenol Int. 2005;30:167-73.

12. Amador MPSC, Barros VRS, Albuquerque PJBS, Buna MIF, Campos JM. Hanseníase na infância no município de Curionópolis - sudeste do Estado do Pará relato de caso. Hansen Int. 2001;26:121-5.

13. Ferreira IN, Alvarez RRA. Hanseníase em menores de quinze anos no município de Paracatu, MG (1994 a 2001). Rev Bras Epidemiol. 2005;8:41-9.

14. Lana FCF, Amaral EP, Lanza FM, Lima PL, Carvalho ACN, Diniz LG. Hanseníase em menores de 15 anos no Vale do Jequitinhonha, Minas Gerais, Brasil. Rev Bras Enferm. 2007;60:696-700.

15. Ripsa.org [Internet]. Ministério da Saúde. Secretaria de Vigilância em Saúde. RIPSA [accessed on 5th January, 2011]. Available at: http://www.ripsa.org.br/php/level.php?lang=pt\&component=56\&item $=22$
16. Portal.saude.org [Internet]. Ministério da Saúde. Secretaria de Atenção a Saúde. Relatório de Gestão 2009. Brasília: Ministério da Saúde; 2010. [accessed on 5th January, 2011]. Available at: http://portal.saude.gov.br/portal/arquivos/pdf/relatorio_gestao_sas_2009.pdf

17. Goulart IM, Bernardes Souza DO, Marques CR, Pimenta 18 VL, Goncalves MA Goulart LR. Risk and protective factors for leprosy development determined by epidemiological surveillance of household contacts. Clin Vaccine Immunol 2008;15:101-5.

18. Gomes CCD, Penna GO, Aires MAP, Gonçalves HS. Perfil clínico-epidemiológico dos pacientes diagnosticados com hanseníase em um centro de referência na região nordeste do Brasil. An Bras Dermatol. 2005;80(Suppl.3):S283-8.

19. Opromolla PA, Dalben I, Cardim M. Análise geoestatística de casos de hanseníase Rev Saúde Pública. 2006;40:907-13.

20. Costa ALF, Oliveira ML Wan Del Rei. Falhas da vigilância epidemiológica da hanseníase: 4 casos multibacilares em crianças, no estado do PI. Hansen Int. 2009;34:41-6.

21. Façanha MC, Pinheiro AC, Lima JRC, Ferreira MLLT, Teixeira GFD, Rouquayrol MZ. Hanseníase: subnotificação de casos em Fortaleza - Ceará, Brasil. An Bras Dermatol. 2006;81:329-33.

22. Cunha MD, Cavaliere FAM, Hércules FM, Duraes SMB, Oliveira MLWDR. Os indicadores da hanseníase e as estratégias de eliminação da doença em município endêmico do estado do Rio de Janeiro, Brasil. Cad Saúde Pública. 2007;23:1187-97.

23. Magalhães MCC, Rojas LI. Evolución de la endemia de la lepra en Brasil. Rev Bras Epidemiol 2005;8:342-55.

24. Kerr-Pontes LRS, Barreto ML, Evangelista CMN, Rodrigues LC, Heukelbach J, Feldmeier H. Socioeconomic, environment, and behavioural risk factors for leprosy in North-east Brazil: results of a case-control study. Int J Epidemiol. 2006;35:994-1000.

25. Goulart IMB, Arbex GL, Carneiro MH, Rodrigues MS, Gadia R. Efeitos adversos da poliquimioterapia em pacientes com hanseníase: um levantamento de cinco anos em um Centro de Saúde da Universidade Federal de Uberlândia. Rev Soc Bras Med Trop. 2002;35:453-60.

26. Pedroso M, Oliveira S, Bacarlli R, Vieira PCT, Gonçalves A. Incapacidades físicas em hanseníase: estudo multicêntrico da realidade brasileira. An Bras Dermatol. 1989;64:301-6.

MAILING ADDRESS:
Manoel Wilkley Gomes de Sousa
SGAN 911 Conjunto F bloco H Apt 122 condominio
Green Park Asa norte
$70790-110$ Brasília - DF
Telephone: +556181727853
E-mail:wilkleyimp@botmail.com

How to cite this article: Sousa MWG, Silva DC, Carneiro LR, Almino MLBF, Costa ALF. Epidemiological Profile of Leprosy in the Brazilian state of Piauí between 2003 and 2008. An Bras Dermatol. 2012;87(3):389-95. 